\title{
Is There Mixing of American Plaice Populations in the Flemish Pass?
}

\author{
M. J. Morgan and W. R. Bowering \\ Dept. of Fisheries and Oceans, P. O. Box 5667 \\ St. John's, NL, Canada A1C 5X1
}

Morgan, M. J., and W. R. Bowering. 2006. Is there mixing of American plaice populations in the

Flemish Cap. J. Northw. Atl. Fish. Sci., 37: 73-80. doi:10.2960/J.v37.m559

\begin{abstract}
American plaice (Hippoglossoides platessoides) on the Grand Bank (Divisions 3LNO) and Flemish Cap (Div. 3M) are thought to represent separate populations. However, in the late 1980s and early 1990s there was a change in the distribution of American plaice in the region. They were found in the deep waters of the Flemish Pass and in addition, the Grand Bank population as a whole was found in deeper waters. This raises the possibility of mixing between the two populations, at least in the area of the Flemish Pass. The purpose of this study was to examine the distribution, size and maturation of American plaice in the Flemish pass to help determine if fish in that area are a mix of fish from the two adjacent populations or if the fish remain separated there. American plaice collected from the western (Div. 3L) and eastern (Div. 3M) sides of the Flemish Pass were clearly different in mean length-at-age and in their maturation, with fish from the eastern side being larger at age and females maturing at a smaller size than those from the western or Grand Bank side of the Flemish Pass. Further, American plaice were not collected in the deepest part of the Pass that was surveyed. Thus it seems that fish in the Flemish Pass area are not mixing but rather are separate groups.
\end{abstract}

Key words: American plaice, Flemish Cap, Flemish Pass, Grand Bank, stock mixing

\section{Introduction}

American plaice (Hippoglossoides platessoides) is a flatfish species that is found throughout the north Atlantic. In the Northwest Atlantic it is distributed from west Greenland in the north to the Gulf of Maine off the eastern United States (Scott and Scott, 1988). This distribution includes the Grand Bank (Div. 3LNO) and the Flemish Cap (Div. 3M, Fig. 1). The population on the Grand Bank has historically been much larger than that on the Flemish Cap, supporting fisheries of 50000 tons, compared to a fishery of only a few thousand tons on the Flemish Cap (Bowering and Brodie, 1991). Both populations have declined in abundance to very low levels and are under moratoria to directed fishing (Alpoim et al., MS 2002; Morgan et al., MS 2003).

The populations on the Flemish Cap and on the Grand Bank are thought to be separate with little or no connection between them (Pitt, 1963), however there have been no genetic studies comparing fish from the two areas. Pitt (1963) found significant differences in the number of vertebrae between fish on the Grand Bank and those on Flemish Cap. Analyses of ichthyoplankton distribution and oceanographic currents led to the conclusion that eggs and larvae of American plaice spawning in the area would not drift long distances (Nevinsky and Serebryakov, MS 1973). The parasitic fauna of
American plaice was also found to differ between the two areas (Zubchenko, 1985). An examination of distribution, growth, age composition and maturity by Bowering and Brodie (1994) indicated that American plaice on the Flemish Cap were distributed in warmer waters, were bigger at age and had a truncated age distribution compared to fish on the Grand Bank.

In the late 1980s, early 1990s American plaice were found in the deep waters of the Flemish Pass (Iglesias et al., 1996). In addition, the Grand Bank population as a whole was found in deeper waters (Morgan and Colbourne, 1999; Morgan, 2001). This raises the possibility of mixing between the two populations, at least in the area of the Flemish Pass.

The purpose of this study was to examine the distribution, size-at-age and maturation of American plaice in the Flemish pass to help determine if fish in that area are a mix of fish from the two adjacent populations or if the fish remain separated there.

\section{Materials and Methods}

Surveys conducted by the Canadian Department of Fisheries and Oceans on the Grand Bank and Flemish Cap and in the deep water of the Flemish Pass were 

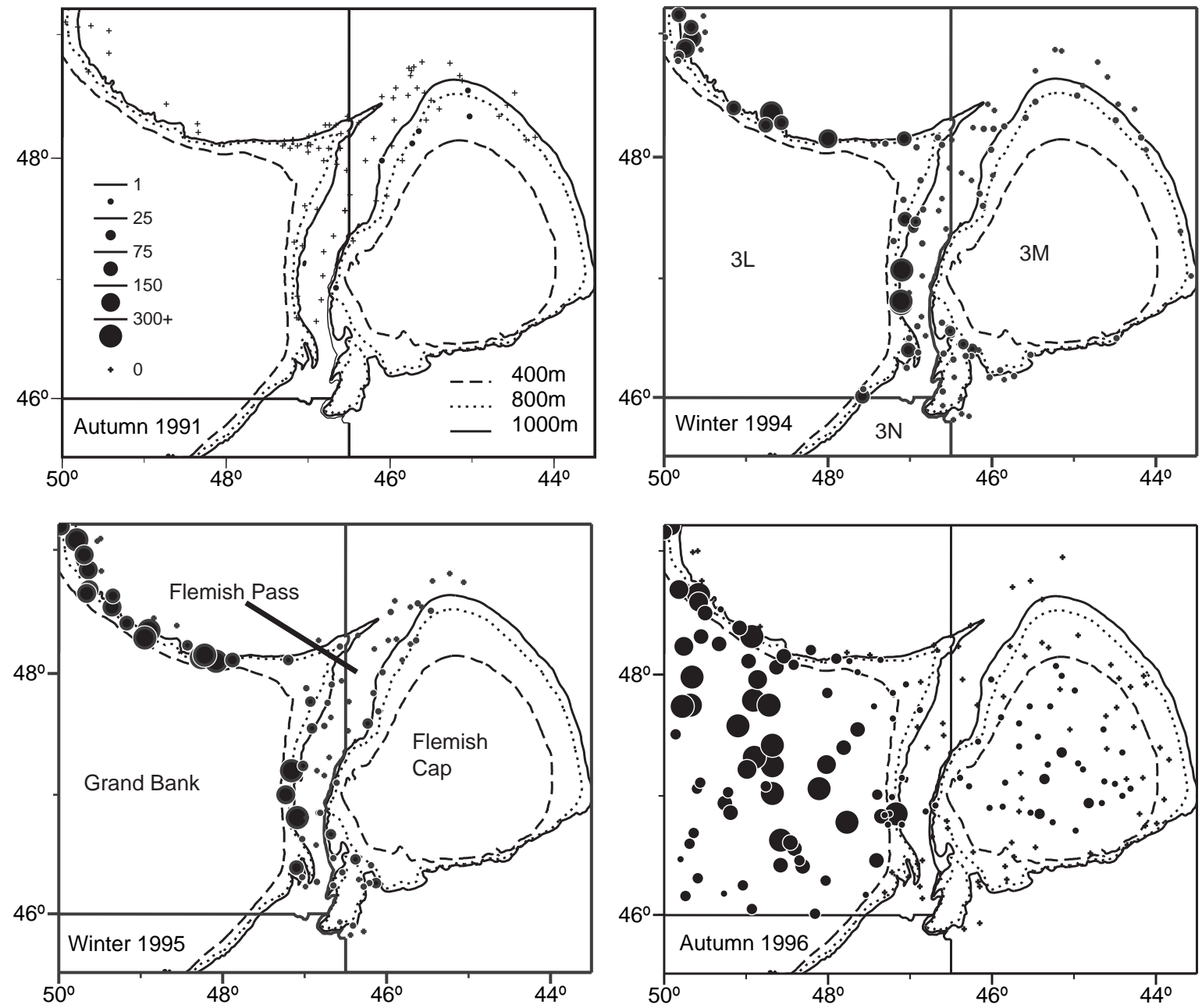

Fig. 1. Distribution of number of American plaice caught in surveys covering the area of the Flemish Pass.

examined (Table 1). There were some differences in survey gear, as well as tow duration and speed, so that care should be taken in comparing between surveys. All surveys, except the early autumn 1991 and winter 1994 deep water surveys, collected number, weight, length, sex and maturity data on every tow containing American plaice, as well as otoliths for ageing. The other two surveys recorded number and weight on every set but did not collect otoliths or record length frequencies. During the winter 1994 survey a special collection of otoliths, length, sex and maturity was made from four sets on either side of the Flemish Pass.

Distribution maps were produced using A CONtouring application (ACON) for those surveys that spanned the Flemish Pass (early autumn 1991, winter 1994 and 1995 and autumn 1996). From these surveys the maximum depth surveyed as well as the maximum depth at which American plaice were found was determined.
Mean length-at-age for males and females was calculated accounting for the length stratified nature of the sampling. Mean length-at-age was then compared within the winter 1994 and 1995 surveys for fish caught on the Grand Bank (western) and Flemish Cap (eastern) sides of the Pass. In addition, mean length-at-age for these fish was compared to that for fish caught during the spring 1994 northern Grand Bank (Div. 3L only) and autumn 1996 Flemish Cap surveys. The autumn survey in 1996 had a different selectivity because of the different fishing gear used but it is the only survey of all of the Flemish Cap conducted by Canada during this time period.

Maturity-at-size and age was also compared for fish caught on either side of the Flemish Pass during the 1994 and 1995 deep-water surveys. These were also compared to the spring 1994 and autumn 1996 surveys. Maturity data from the spring 1995 survey of the northern Grand Bank were also examined. Observed proportion 
TABLE 1. Details of surveys.

\begin{tabular}{|c|c|c|c|c|c|c|c|c|}
\hline Survey & Year & Months & Vessel & Divisions & $\begin{array}{l}\text { Depth range } \\
(\mathrm{m})\end{array}$ & Gear & $\begin{array}{c}\text { Tow } \\
\text { duration }\end{array}$ & $\begin{array}{l}\text { Tow } \\
\text { speed }\end{array}$ \\
\hline Deep water & 1991 & $\begin{array}{c}\text { Sep } \\
\text { Autumn }\end{array}$ & Cape Adair & $3 \mathrm{KLM}$ & $750-1500$ & Engel 145 & $30 \mathrm{~min}$ & 3.5 knots \\
\hline Deep water & 1994 & $\begin{array}{l}\text { Feb-Mar } \\
\text { Winter }\end{array}$ & Zandvoort & 3KLMN & $550-1500$ & Engel 145 & $30 \mathrm{~min}$ & 3.5 knots \\
\hline Deep water & 1995 & $\begin{array}{l}\text { Mar-Apr } \\
\text { Winter }\end{array}$ & Teleost & 3KLMN & $500-1500$ & Engel 145 & $30 \mathrm{~min}$ & 3.5 knots \\
\hline $\begin{array}{l}\text { Spring } \\
\text { Grand Bank }\end{array}$ & $\begin{array}{l}1994- \\
1995\end{array}$ & $\begin{array}{l}\text { May-June } \\
\text { Spring }\end{array}$ & $\begin{array}{c}\text { Wilfred } \\
\text { Templeman }\end{array}$ & $3 \mathrm{~L}$ & to 750 & Engel 145 & $30 \mathrm{~min}$ & 3.5 knots \\
\hline $\begin{array}{l}\text { Autumn } \\
\text { Flemish Cap }\end{array}$ & 1996 & $\begin{array}{l}\text { Nov-Dec } \\
\text { Autumn }\end{array}$ & $\begin{array}{c}\text { Wilfred } \\
\text { Templeman, } \\
\text { Teleost }\end{array}$ & $3 \mathrm{LM}$ & to 1500 & $\begin{array}{c}\text { Campelen } \\
1800\end{array}$ & $15 \mathrm{~min}$ & 3.0 knots \\
\hline
\end{tabular}

mature-at-age was calculated according to the method of Morgan and Hoenig (1997), accounting for the length stratified sampling. Proportion mature-at-length or age was estimated using generalized linear models with binomial error and a logit link function $\left(\mathrm{M}^{\mathrm{c}} \mathrm{Cullagh}\right.$ and Nelder, 1983). These same models were used to test for significant differences between areas. Because of the limited data, estimates were made across year rather than by cohort. Length and age were modelled as continuous variables while the effect of area was a class variable. For the logit link function,

$$
\eta=\log \left(\frac{\mu}{1-\mu}\right)
$$

and

$$
\hat{\mu}=\left(\frac{1}{1+\exp (-\widehat{\eta})}\right)=\text { proportion mature }
$$

where $\eta=\tau+\gamma \mathrm{B}+\psi_{i}, \tau$ is an intercept, $\gamma$ is the age or length effect, $B$ is the length or age, and $\psi_{i}$ is the area effect. Significance was tested through analyses of deviance where change in deviance with the addition of an explanatory variable is approximately distributed as $\chi^{2}$.

\section{Results}

In the Cape Adair survey in early autumn 1991, no American plaice were captured in the Grand Bank or western side of the Flemish Pass. The maximum depth of the survey of the eastern side of the Flemish Pass was $1495 \mathrm{~m}$ and American plaice were caught to a depth of 1 $000 \mathrm{~m}$. In the other three surveys that covered the Flemish Pass area, American plaice were distributed on both the western and eastern sides of the Pass (Fig. 1). However, in sets that occurred in the middle of the Pass and at the greatest depths, no American plaice were found. In the winter 1994 survey, the maximum depth surveyed was $1421 \mathrm{~m}$, while American plaice were only caught to a depth of $1241 \mathrm{~m}$. In the winter 1995 survey, American plaice were found to a depth of $1281 \mathrm{~m}$ while the deepest survey set was $1425 \mathrm{~m}$. The deepest survey sets in the autumn 1996 survey in the area were $1433 \mathrm{~m}$, while American plaice were not found beyond $1383 \mathrm{~m}$.

There was a clear difference in mean size-at-age between fish found on the two sides of the Flemish Pass. This was true both in the special collection made in 1994 and in the full collection covering the whole area in winter 1995 (Fig. 2). Fish on the eastern side of the Pass were bigger at age than those on the western side for both males and females. The fish sampled from the western side of the Pass in both 1994 and 1995 were very similar in size to the average size-at-age of those fish sampled throughout the Grand Bank during the spring 1994 survey. Fish sampled on the eastern side of the pass during the winter 1994 and 1995 deep water surveys were very similar in mean size-at-age to those sampled over the whole of the Flemish Cap during the autumn 1996 survey, even though that survey used a different gear.

Proportion mature-at-length could only be estimated for females in the Flemish Pass, as there was no significant model fit to the male data. Females matured at a significantly smaller size on the western side of the Pass, as 

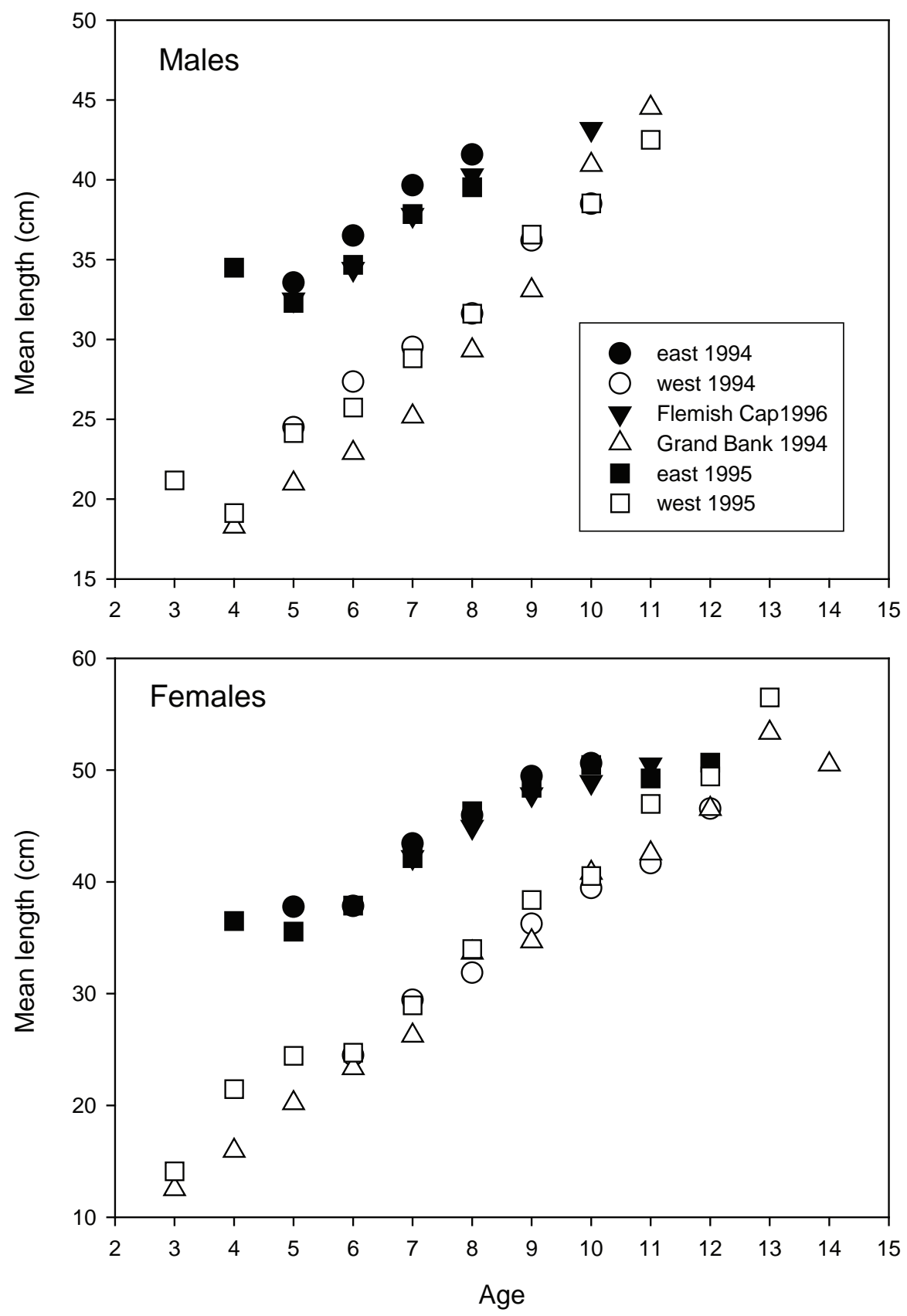

Fig. 2. Mean length-at-age (cm) for male and female American plaice. East and west 1994 and 1995 refer to fish caught on the eastern (Div. 3M) and western (Div. 3L) sides of the Flemish Pass during the 1994 and 1995 winter deep water surveys. Flemish Cap 1996 refers to fish caught during the autumn 1996 survey of the Flemish Cap. Grand Bank 1994 refers to fish caught in northern Grand Bank (Div. 3L) during the spring 1994 survey.

compared to those fish sampled on the eastern side of the Pass in both the 1994 and 1995 deep water surveys (Fig. 3 , Table 2). Maturity-at-length for fish sampled in the deep water on the western side of the pass in 1994 was not significantly different from those sampled in same area in 1995. Similarly, the eastern deep water samples in 1994 and 1995 were not significantly different from one another. Fish sampled in the 1994 and 1995 deep 
MORGAN and BOWERING: Mixing of American Plaice Populations in the Flemish Pass?
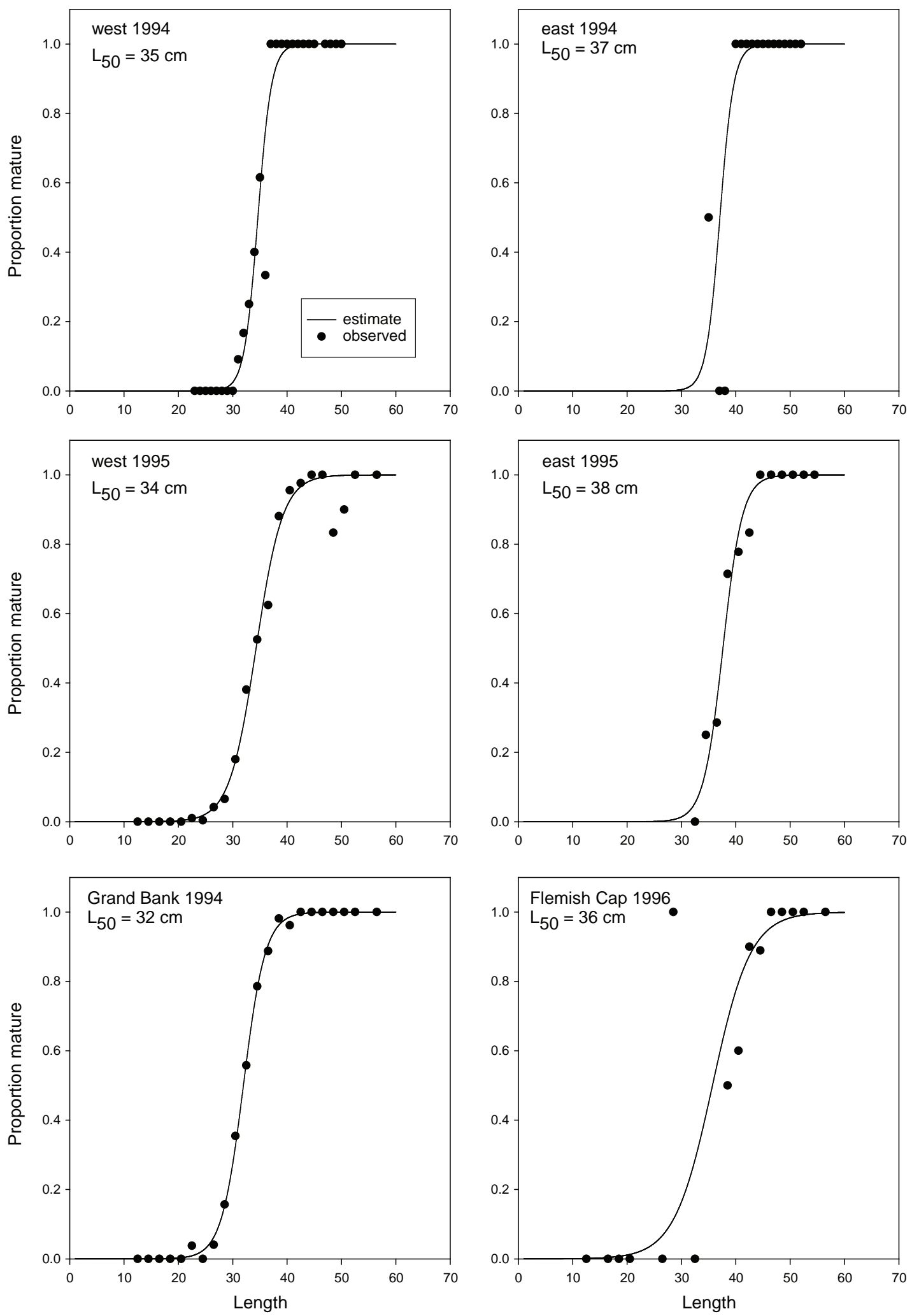

Fig. 3. Proportion mature-at-length for female American plaice sampled during various surveys. The line gives estimated proportion and the dots are the observed values. The length at $50 \%$ maturity is given on each panel. The designations for the surveys are as given in Fig. 2. 
TABLE 2. Results of generalized linear models comparing proportion mature-at-size or age for female American plaice found in Div. 3L and 3M. All tests have 1 d.f.

\begin{tabular}{lrr}
\hline \hline Comparison & $\chi^{2}$ & $p$ \\
\hline Maturity-at-length & & \\
Deep water 1994 east (3M) vs west (3L) & 8.8 & $<0.005$ \\
Deep water 1995 east vs west & 4.6 & $<0.05$ \\
Deep water west 1994 vs 1995 & 3.0 & $\mathrm{NS}$ \\
Deep water east 1994 vs 1995 & 0.1 & $\mathrm{NS}$ \\
Deep water east 1994 vs autumn Flemish Cap 1996 & $\mathrm{NS}$ \\
Deep water east 1995 vs autumn Flemish Cap 1996 & 0.5 \\
Deep water west 1994 vs spring Grand Bank 1994 & 0.3 & $<0.0001$ \\
Deep water west 1995 vs spring Grand Bank 1994 & 106 & $<0.0001$ \\
Deep water west 1995 vs spring Grand Bank 1995 & 46 & $<0.0001$ \\
Maturity-at-age & 15.3 & $<0.0001$ \\
Deep water 1995 east $v s$ west & & $<0.0001$ \\
Deep water west 1995 vs spring Grand Bank 1995 & 23.2 & 17.7 \\
\hline
\end{tabular}

water surveys from the eastern side of the Pass did not have significantly different maturities-at-length than those sampled over the entire Flemish Cap during the autumn 1996 survey. However, the proportion matureat-length for fish in the deepwater in the western part of the Pass in 1994 and 1995 was significantly different from fish sampled over the northern Grand Bank during the spring 1994 survey (Table 2).

There was only a significant fit of the model to proportion mature-at-age data for females. There was no significant model fit for the deep water survey in 1994 or for fish collected on Flemish Cap during the autumn 1996 survey. The fish sampled from the western side of the Pass during the deepwater survey in 1995 matured at a significantly older age than those collected from the eastern side during that survey (Fig. 4, Table 2). Again there was a significant difference in proportion matureat-age for fish from the western side of the Pass in the 1995 deep water survey vs. those in the entire northern Grand Bank area during the 1995 spring survey.

\section{Discussion}

American plaice collected from the Grand Bank and Flemish Cap sides of the Flemish Pass were clearly different in mean length-at-age and in their maturation. Further, American plaice were not collected in the deepest part of the Pass that was surveyed. While the types of information examined here can not give a definitive conclusion about stock mixing, it seems that fish in the Flemish Pass area are not mixing but rather are separate groups.
The origin of the fish on either side of the Pass appears to be the adjacent populations. That is, the fish on the western side of the pass appear to be from the northern Grand Bank while those on the eastern side of the Pass appear to be from the Flemish Cap population. The mean lengths-at-age were very similar between the fish in the Pass and those from the adjacent populations. The proportion mature-at-length was also the same for fish from the eastern side of the pass and fish from the whole of the Flemish Cap. There were however, significant differences between the proportion mature-at-size and age for fish from the northern Grand Bank compared to those found on the western side of the Flemish Pass. It is not known why mean length-at-age would be so similar between fish from the entire northern Grand Bank area and those on the western side of the Pass while maturation was different. The fish collected during the spring survey of the northern Grand Bank came from a very wide geographic area, experiencing a variety of environmental conditions. It is possible that maturation is more sensitive to varying conditions than growth.

The occurrence of American plaice in the deep water of the Flemish Pass appears to be a seasonal phenomenon, with fish being found in higher abundance in the area in the winter and spring (Iglesias et al., 1996, reports from the Canadian fishing industry). Seasonal changes in distribution in this species, including changes in depth, are not uncommon (Morgan and Brodie, 1991; Powles, 1965; Swain et al., 1998). The reasons for the changes in distribution are not known but could be related to temperature selection/avoidance and/or seasonal patterns in foraging. 
MORGAN and BOWERING: Mixing of American Plaice Populations in the Flemish Pass?
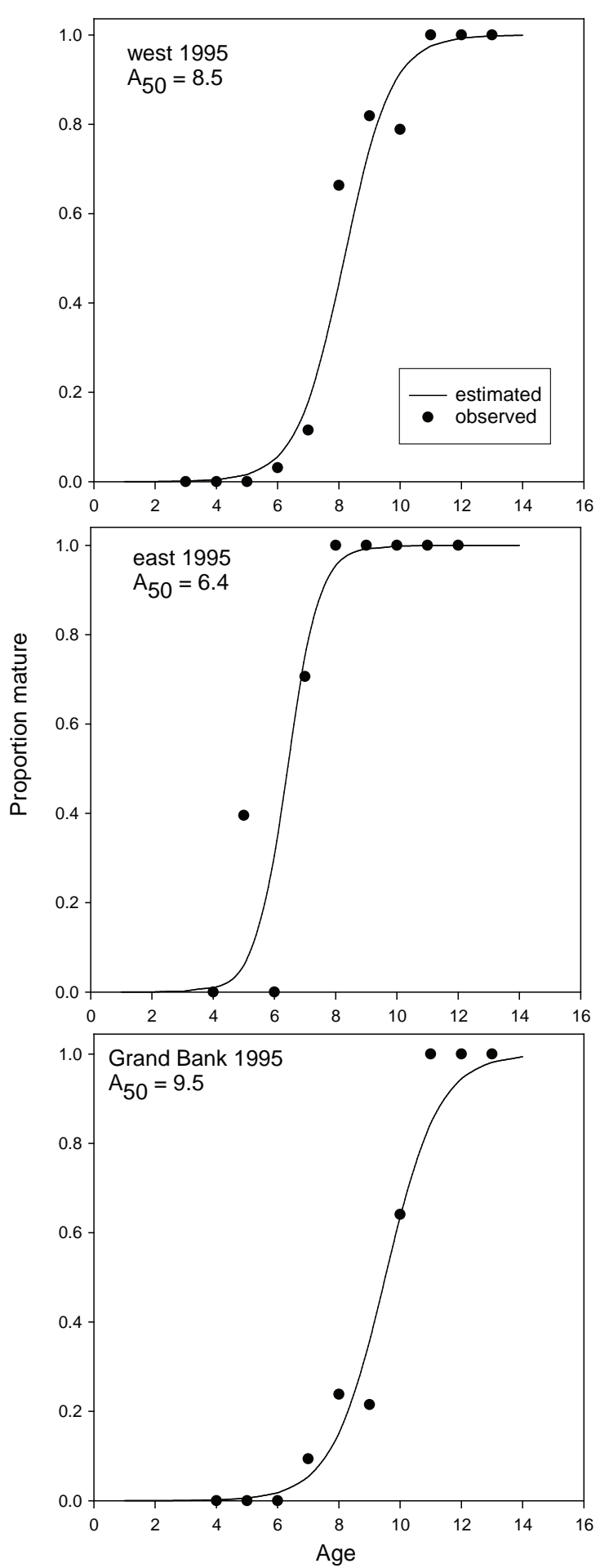

Fig.4. Proportion mature-at-age for female American plaice sampled during various surveys. The line gives estimated proportion and the dots are the observed values. Age at $50 \%$ maturity is given on each panel. The surveys are designated as in Fig. 2 except for the bottom panel which represents the spring survey of the northern Grand Bank (Div. 3L) in 1995.
It is not clear whether American plaice have always been found in this area during the winter spring period. The study by Iglesias et al. (1996) found some interannual variability in the timing and abundance of American plaice in deep water. There has also been a change in the depth distribution of American plaice captured in the spring survey of the northern Grand Bank with American plaice being found deeper starting in the early 1990s (Morgan, 2001). The earliest survey examined here (1991) did not detect any American plaice in the deep waters of the eastern side of the Pass and only few on the western side. However, this survey was in September and may have occurred before any seasonal movement into deeper water. Although data may not exist to determine the beginning of this phenomenon, continued monitoring of commercial catches in the area would provide information on whether or not it continues.

\section{Acknowledgements}

We thank the many technical staff and ships crew involved in the collection of these data. An earlier version of the manuscript benefited greatly from comments by S. Cadrin and an anonymous reviewer.

\section{References}

ALPOIM, R., C. DARBY, and A. AVILA DE MELO. MS 2002. An assessment of American plaice (Hippoglossoides platessoides) in NAFO Division 3M. NAFO SCR Doc., No. 62, Serial No. N4674, 37 p.

BOWERING, W. R. and W. B. BRODIE. 1991. Distribution of commercial flatfishes in the Newfoundland-Labrador region of the Canadian Northwest Atlantic and changes in certain biological parameters since exploitation. Neth. J. Sea Res., 27: 407-422.

1994. Distribution, age and growth and sexual maturity of American plaice (Hippoglossoides platessoides (Fabricius)) on Flemish Cap (NAFO Division 3M). J. Northw. Atl. Fish. Sci., 16: 49-61.

IGLESIAS, S., J. PAZ, and E. DE CARDENAS. 1996. Occurrence of American plaice (Hippoglossoides platessoides) at non-habitual depths in the northwest Atlantic, 1990-93. NAFO Sci. Coun. Studies, 24: 91-95.

M CULLAGH, P., and J.A. NELDER. 1983. Generalized Linear Models. London, Chapman and Hall.

MORGAN, M. J. 2001. Time and location of spawning in American plaice in NAFO Divisions 3LNO. J. Northw. Atl. Fish. Sci., 29: 41-49.

MORGAN, M. J., and W. B. BRODIE. 1991. Seasonal distribution of American plaice on the northern Grand Banks. Mar. Ecol. Prog. Ser., 75: 101-107.

MORGAN, M. J. and E. B. COLBOURNE. 1999. Variation in maturity-at-age and size in three populations of American plaice. ICES J. Mar. Sci., 56: 673-688.

MORGAN, M. J., and J. M. HOENIG. 1997. Estimating age at maturity from length stratified sampling. J. Northw. Fish. 
Sci., 21: 51-63.

MORGAN, M. J., W. B. BRODIE, D. MADDOCK PARSONS, and B. P. HEALEY. MS 2003. An assessment of American plaice in NAFO Divisions 3LNO. NAFO SCR Doc., No. 56, Serial No. N4874, 70 p.

NEVINSKY, M. M., and V. P. SEREBRYAKOV. MS 1973. American plaice, Hippoglossoides platessoides platessoides Fabr., spawning in the northwest Atlantic area. ICNAF Res. Bull., 10: 23-36.

PITT, T. K. 1963. Vertebral numbers of American plaice, Hippoglossoides platessoides (Fabricius), in the Northwest Atlantic. J. Fish. Res. Board Can., 20: 1159-1181.

POWLES, P. M. 1965. Life history and ecology of American plaice (Hippoglossoides platessoides F.) in the Magdalen Shallows. J. Fish. Res. Bd. Canada, 22: 565-598.

SCOTT, W. B., and M. G. SCOTT. 1988. Atlantic fishes of Canada. Can. Bull. Fish. Aquat. Sci., 219: 731 p.

SWAIN, D. P., G. A. CHOUINARD, R. MORIN, and K. F. DRINKWATER. 1998. Seasonal variation in the habitat associations of Atlantic cod (Gadus morhua) and American plaice (Hippoglossoides platessoides) from the southern Gulf of St. Lawrence. Can. J. Fish. Aquat. Sci., 55: 2548-2561.

ZUBCHENKO, A. V. 1985. Parasitic fauna of American plaice (Hippoglossoides platessoides) from the Northwest Atlantic. J. Northw. Atl. Fish. Sci., 6: 165-171. 